\title{
Våren är här
}

VÅREN ÄR HÄR och vi kämpar alla med att hinna det vi lovat att göra klart innan sommaren. Så också Sociologförbundet. Just nu är vi i full gång med att planera Sociologidagarna 2022, som kommer att äga rum i Uppsala. Sociologiska institution vid Uppsala universitet står som värd för konferensen och gör lejonparten av arbetet.

Under vårterminen anordnade vi också ett mycket välbesökt och uppskattat webbinarium kring detta temanummer om covid-19-pandemin. Det blev väldigt lyckat och vi hoppas att liknande webbinarium kring Sociologisk Forsknings framtida temanummer blir ett stående inslag i vår verksamhet.

Under våren - närmare bestämt den 20 maj - lanserade vi ytterligare ett nytt inslag i Sociologförbundets verksamhet. Vi inledde en serie med webbinarier kring priset för bästa avhandling som ges ut av förbundet. Först ut var Lisa Flower, som fick 2020 års pris för sin avhandling om försvarsadvokaters emotionella arbete under brottmålsrättegångar. Nästföljande gång priset delas ut kommer seminariet anordnas strax efter att Sociologidagarna har gått av stapeln.

Till sist, glöm inte att meddela förbundet om ni har några nyheter som bör läggas ut på vår hemsida eller vår sida på Facebook. Det kan handla om nya tjänster, intressanta kurser, seminarier, etcetera.

Hälsningar

Kenneth Nelson

Ordförande för Sveriges Sociologförbund 